Vol.45, Special n. : pp. 57-59, September 2002

ISSN 1516-8913 Printed in Brazil

\title{
Radiolabeled PNAs for Imaging Gene Expression
}

\author{
Eric Wickstrom; Edward Sauter; Xianben Tian; Sampath Rao; Weyng Quin and Mathew \\ Thakur* \\ Thomas Jefferson University; PA 19107; Philadelphia - USA
}

\begin{abstract}
Scintigraphic imaging of gene expression in vivo by non-invasive means could precisely direct physicians to appropriate intervention at the onset of disease and could contribute extensively to the management of patients. However, no method is currently available to image specific overexpressed oncogene mRNAs in vivo by scintigraphic imaging. Nevertheless, we have observed that Tc-99m-peptides can delineate tumors, and that PNApeptides are specific for receptors on malignant cells and are taken up specifically and concentrated in nuclei. We hypothesize that antisense Tc-99m-PNA-peptides will be taken up by human breast cancer cells, hybridize to complementary mRNA targets, and permit imaging of oncogene mRNAs in human breast cancer xenografts in a mouse model, providing a proof-of-principle for non-invasive detection of precancerous and invasive breast cancer. Oncogenes cyclin D1, erbB-2, c-MYC, and tumor suppressor p53 will be probed. If successful, this technique will be useful for diagnostic imaging of other solid tumors as well.
\end{abstract}

Key words: Radiolabeled PNAs, scintigraphy imaging, gene expression

\section{INTRODUCTION}

Radiolabeled DNA antisense have been evaluated for imaging gene expression in vivo (Shi et al., 2000; Zheng and Tan, 2001). The success, however, is limited by several factors, including rapid metabolism in vivo, toxicity, and poor transport of antisense compounds across the cell membranes. Peptide nucleic acids (PNA) are DNA analogs in which phosphase sugar backbone is replaced with 2-amino-ethyl glycine. PNAs display superior stability and resist nuclease attack in vivo, and demonstrate antisense activity, and hybridization ability (Hanvey et al., 1992).

Altered gene expression on a cellular level leads to malignancy. These biochemical changes occur before cellular morphologic changes are apparent.
However, no method is currently available that can detect gene expression, non-invasively, in vivo.

We hypothesized that radiolabeled PNA will target malignant cells, hybridize to complementary mRNA, and permit early imaging of oncogene mRNA in human cancer cells by external detection, non-invasively.

\section{METHODS}

Taking early imaging of breast cancer as an example, we opted to probe such oncogenes as cyclin D1, erbB-2, c-myc, and tumor suppressor p53, known to play a pivotal role in breast cancer (Adelaide et al., 1995; Slamon et al., 1998; Berns et al., 1992; Meng et al., 1999). Specifically, 12 mer PNA were chosen for radiolabeling and

\footnotetext{
* Author for correspondence
} 
corresponding 4 codon mismatch PNAs as controls. In order to be able to label the PNA with an imaging radionuclide as Tc-99m, the PNAs were modified at 3 ' with a chelating agent consisting of four amino acids, Gly-D-Ala-GlyGly. 4-amino butyric was placed as a spacer between the PNA and the chelating moiety to minimize steric hindrance. In order to provide specific malignant cell specificity, the PNAs were also modified at 5' with an additional group of amino acids specific for insulin-like growth factor (IGFR) expressed in high density in most cancerous breast epithelial cells. The entire construct was synthesized, purified, and analyzed using matrix-assisted laser desorption ionization (MALDI) mass spectrometer (Thakur et al., 2000; Thakur et al., 2000).

Purified PNA constructs were labeled with Tc$99 \mathrm{~m}$ in $\mathrm{m}$ mol quantities. Quality control was performed using RP-C-18-HPLC and instant thin layer chromatography. Using MCF-7 human breast tumor cell line, mRNA RT-PCR hybridization analysis was performed for each of the above genes (Wickstrom et al., 1986). For cMYC specific Tc-99m-PNA cell binding assay were carried out and tumors grown in nude mice by implanting human breast cancer cell lines were targeted.

\section{RESULTS}

Chelator-PNAs were successfully synthesized with $100 \%$ purity. Tc-99m labeling efficiency was $>97 \%$ (specific activity $3.6 \mathrm{Ci} / \mathbf{m m}$ ), colloid formation was $<2 \%$. The Tc- $99 \mathrm{~m}-\mathrm{PNA}$ was eluted as a single HPLC peak, which indicated excellent radiochemical purity. CyclinD, erbB-2, c-MYC, and p53 genes were reliably amplified and compared to a control gene TPB. Kd values for cMYC specific PNA was $10^{-9} \mathrm{M}$.

Tumors were delineated at $4 \mathrm{hr}$ post-injection. Tc99m-PNAs were eliminated by renal excretion in which free Tc- $99 \mathrm{~m}<2 \%$.

\section{DISCUSSION}

This is a work in progress. We have shown thus far that an efficient chelator-PNA synthesis is feasible. Our data suggest that the newly synthesized agents have high affinity for specific targeted receptors. The data also demonstrate that the peptide-PNA hybridize with specific mRNA and down-regulate gene expression. The preliminary results in experimental animals suggest that the probes are stable in vivo and may be useful for scintigraphic imaging of oncogene expression in human breast and possibly other tumors in vivo.

The work was supported by DOE/ER 63055.

\section{RESUMO}

Imagens cintigráficas da expressão genética in vivo por metódos não invasivos poderiam orientar mais precisamente as intervenções médicas para $o$ local definido da doença e poderia contribuir para melhor tratamento dos pacientes. Entretanto, nenhum método está atualmente disponível para a imagem específica da intensa expressão de um oncogene de RNAm (s) in vivo por imagem cintigráfica. Contudo, nós temos observado que peptídeos marcados Tc-99m podem delinear tumores, e que peptídeos PNA são específicos para receptores em células malignas e são captados e concentrados no núcleo. Nós sugerimos que peptideos PNA nonsense marcados com Tc-99m serão capturados pelas células neoplásicas de mama humana, hibridizarão com sequências complementares de alvos de RNAm e permitirão imagen de oncogenes de RNAm em câncer de mama humana com enxerto em modelo animal, provendo um prova do princípio de detecção câncer de mama em estado pré-cancer e não invasivo. Oncogenes ciclin D1, erb B-2, c-MYC, e um tumor supressor p53 irão ser explorados. Se obtivermos sucesso, está técnica também irá ser útil no diagnóstico de imagens de outros tumores sólidos.

\section{REFERENCES}

Adelaide, J.; Monges, G. and Derderian, C. et al. (1995), Oesophagea/cancer and amplification of human cyclin D gene CCND1/PRAD1. Br. J. Cancer, 71, 64-68.

Berns, E. M.; Klijn, J. G. and VanPutten, W. L. et al. (1992), c-MYC amplification is a better prognostic factor than Her2/neu amplification in primary breast cancer. Cancer Res., 52, 1107-1113. 
Hanvey, J. C.; Peffer, N. J. and Bisi, J. E. et al. (1992), Antisense and antigen properties of peptide nucleic acid. Science, 258, 1481-1485.

Meng, L.; Lin, L. and Zhang, H. et al. (1999), Multiple mutation of the p53 gene in human mammary carcinoma. Mutal. Res., 435, 263-269.

Shi, N.; Boado, R. J. and Pardridge, W M. (2000), Antisense imaging of gene expression in the brain in vivo. Proc. Nat. Acad. Sci., 97, 14709-14714.

Slamon, D.; Clark, G. M. and Wong, S. G. et al. (1998), Addition of Herceptin (humanized anti-human HER2 antibody) to first line chemotherapy for HER2 overexpressing metastatic breast cancer markedly increases anticancer activity: A randomized multinational controlled phase III trial. Proc. Am. Soc. Clin. Oncol., 17, 98-101.

Thakur, M. L.; Marcus, C. S. and Saeed, S. et al. (2000), 99mTc-labeled vasoactive intestinal peptide analog for rapid localization of tumors in humans. J. Nucl. Med., 41, 107-110.
Thakur, M. L.; Pallela, V. R. and Consigny, P. M. et al. (2000), Imaging vascular thrombosis with 99mTclabeled fibrin alpha-chain peptide. J. Nucl. Med., 41, 161-168.

Wickstrom, E. L.; Wickstrom, E.; Lyman, G. H. and Freeman, D.L. (1986), HL60 cell proliferation inhibited by an anti-c-MYCpentadecadeoxynucleotide. Fed. Prof., 45, 708.

Zheng, J. and Tan, T. (2001), Applications of radionuclide antisense therapy for malignant tumors. Nucl. Med. Comm., 22, 469-472.

Received: July 12, 2002; Revised: July 13, 2002; Accepted: July 14, 2002. 